\title{
Effects of Alkalosis on Plasma Concentration and Urinary Excretion of Inorganic Phosphate in Man*
}

\author{
Marvous E. Mostellar † and Elbert P. Tuttle, Jr.† \\ (From the Department of Medicine, Renal and Electrolyte Section, Emory University School \\ of Medicine at Grady Memorial Hospital, Atlanta, Ga.)
}

In 1924, Haldane, Wigglesworth, and Woodrow reported on the effect of reaction changes on human inorganic metabolism (1). They found that respiratory alkalosis caused a sharp fall and respiratory acidosis a sharp rise in serum phosphorus concentration. They also examined metabolic changes induced by oral ingestion of $\mathrm{Na}$ $\mathrm{HCO}_{3}$ or $\mathrm{NH}_{4} \mathrm{Cl}$ for several days, but respiratory compensation would have minimized $\mathrm{pH}$ changes under the conditions of their experiments. They found no significant deviation of serum phosphorus from normal values. The influence of alkalosis on serum and urinary phosphorus has been intermittently observed since that time during experiments on hydrogen ion disturbances in dogs and in man (2-9). However, most recent reviews on phosphorus metabolism and the parathyroids do not mention the effect of blood hydrogen ion concentration or carbon dioxide tension upon the concentration of phosphorus in the serum or upon the urinary excretion and clearance of phosphorus (10-22).

Our study was undertaken to evaluate the range of variation of plasma phosphorus concentration under the influence of elevated blood $\mathrm{pH}$, to ascertain whether hydrogen ion concentration or $\mathrm{CO}_{2}$ content is the critical determinant, and to consider possible explanations for the fall in concentration of phosphorus.

* Submitted for publication July 10, 1963; accepted September 30, 1963.

Presented at the national meeting of the American Federation for Clinical Research, April 30, 1961, Atlantic City, N. J.

Supported by U. S. Public Health Service grants H-4191 (C 1) and A-5002 Met (1).

$\dagger$ This work was done during tenure of a postdoctoral research fellowship of the National Institutes of Health, Bethesda, Md.

$\$$ Holder of the Georgia Heart Association Chair of Cardiovascular Research, Emory University School of Medicine.

\section{Methods}

Sixteen experiments were performed between 8 a.m. and 2 p.m. in eleven healthy young adults from 20 to 40 years of age. Three major experimental designs were used. In six experiments respiratory alkalosis was induced by voluntary hyperventilation. The $\mathrm{PCO}_{2}$ of expired air was monitored with a continuous infrared $\mathrm{CO}_{2}$ analyzer. Breathing was controlled to reduce the endexpiratory $\mathrm{PCO}_{2}$ from a control range of 35 to $40 \mathrm{~mm}$ $\mathrm{Hg}$ to a range of 13 to $20 \mathrm{~mm} \mathrm{Hg}$.

In four experiments hyperventilation without alkalosis was studied as a control. Two of these were conducted with a Bird Mark VIII respirator using both positive and negative pressures. After a control period of selfregulated respiration, hyperventilation was induced by increase in rate and depth of exchange. The inspired gas mixture was adjusted to contain sufficient $\mathrm{CO}_{2}$ to maintain end-expiratory $\mathrm{PCO}_{2}$ at control levels. After stabilization under these conditions, $\mathrm{CO}_{2}$ was removed from the inspired gas mixture, and respiratory alkalosis was induced. In two further experiments voluntary active hyperventilation was carried out in a tent receiving $10 \% \quad \mathrm{CO}_{2}$ and $90 \% \mathrm{O}_{2}$ so that end-expiratory $\mathrm{PCO}_{2}$ was maintained at control levels.

In six other experiments, metabolic alkalosis was induced. $\mathrm{NaHCO}_{3}$, in amounts from 3.5 to $4.5 \mathrm{mEq}$ per kg body weight, was given intravenously over a 30 -minute period in a concentration approximately five times isotonic, and then an equal amount was begun as a sustaining infusion for an additional 90 minutes. Respiration in these experiments maintained end-expiratory $\mathrm{PCO}_{2}$ at $40 \mathrm{~mm}$ $\mathrm{Hg}$ or slightly above.

All subjects were fasting, but glucose was infused at a rate to provide one calorie per minute throughout the experiment. Blood was collected anaerobically from a Riley needle in the radial artery in syringes containing measured amounts of heparin sodium. Arterial bloods bracketing urine specimens were collected during a control period at $-40,-20$, and 0 minutes, during alkalosis and recovery at $+60,+80$, and +100 minutes after beginning the periods. Specimens for $\mathrm{pH}$ and $\mathrm{CO}_{2}$ were placed on ice and analyzed within 1 hour. Specimens for other analyses were centrifuged immediately, and plasma was separated from the cells. Urines were obtained by voiding at the end of 20 -minute periods. Flow rates varied between .5 and $23.4 \mathrm{ml}$ per minute, with a mean flow of $8.5 \mathrm{ml}$ per minute. Flows in seven periods were less than $3 \mathrm{ml}$ per minute.

Whole blood was analyzed for $\mathrm{pH}$, total $\mathrm{CO}_{2}$, and 
hematocrit by the technique of Shock and Hastings (23), as modified by Singer, Shohl, and Bluemle (24). This technique utilizes a photometric determination of $\mathrm{pH}$ and the manometric determination of $\mathrm{CO}_{2}$ by the method of Peters and Van Slyke (25). Blood $\mathrm{PCO}_{2}$ was estimated from the nomogram of Singer and Hastings (26). Plasma, whole blood, and urine inorganic phosphate concentrations were measured by the method of Fiske and Subbarow (27) and expressed as concentrations of phosphorus. Sodium and potassium concentrations were measured with a flame photometer using lithium as an internal standard. Creatinine chromogen was measured in plasma and urine, using a Folin-Wu (28) precipitate and the Jaffe reaction with alkaline picrate as modified by Bonsnes and Taussky (29). Serum calcium was measured by titration with EDTA using murexide as an indicator in the manner of Fales (30). Blood glucose was determined by the method of Somogyi as modified by Nelson (31).

All analyses were performed in duplicate from separate samples of plasma or urine. Urinary clearances were calculated using mid-point serum concentrations for each period. Indexes of analytical precision are listed in the appendix.

Analysis of variance of the data on serum concentrations and renal excretions were carried out according to methods described by Snedecor (32). Missing values were calculated by the least squares method. The data were considered to belong to the category of mixed Model I and Model II samples. Period $\left(P_{1}\right)$ and blood specimens $\left(B_{k(1)}\right)$ within periods were considered fixed effects, whereas subjects $\left(S_{j}\right)$ were random effects. Symbolically :

$$
\mathrm{X}_{1, \mathbf{k}}=\mu+\mathrm{P}_{1}+\mathrm{S}_{\mathbf{j}}+\mathrm{B}_{\mathbf{k}(1)}+(\mathrm{PS})_{1 j}+(\mathrm{BS})_{\mathbf{j} \mathbf{k}(1)} .
$$

Variance ratios were calculated from the appropriate estimated mean squares and compared with the table of "F" ratios for significance (33). Significant contributions of factor means to the total variance are noted in the tables. Because of the occurrence of significant subject-period interactions, no effort was made to quantitate precisely the significance of differences between individual periods. For purposes of summary, simple standard deviations for the variables within each experimental period are given.

\section{Results}

Respiratory alkalosis. Table I gives analyzed and derived data from the blood in six experiments during respiratory alkalosis produced by active hyperventilation. Figure 1 is a graphic representation of the changes in the plasma and blood. It shows the characteristic pattern of respiratory alkalosis with elevation of the mean blood $\mathrm{pH}$ from 7.42 to 7.65 , a fall in the mean whole blood total $\mathrm{CO}_{2}$ from 20.2 to 13.6 mmoles per $\mathrm{L}$, and a fall in mean whole blood $\mathrm{PCO}_{2}$ as calculated by nomo- graph from 38 to $16 \mathrm{~mm} \mathrm{Hg}$. The stability of these variables over the next 40 minutes indicates a relatively steady state of acid-base relationships.

The plasma inorganic phosphorus concentration shows a consistent fall from a mean of .96 to .29 mmole per $\mathrm{L}$ and is proportional to the rise in $\mathrm{pH}$ of the blood. This is also apparent in the fall of

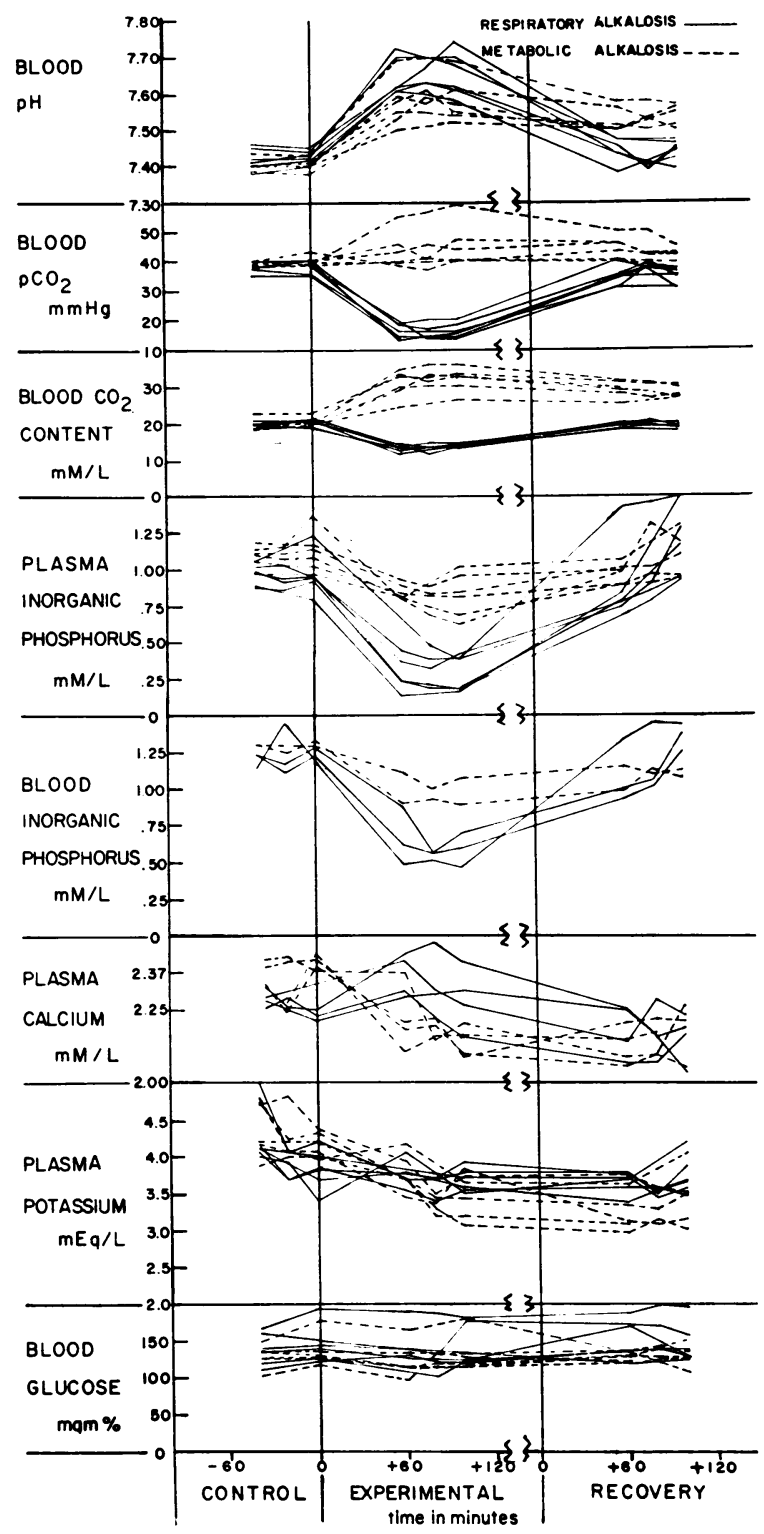

Fig. 1. Pattern of experimental alkalosis. Blood or plasma concentrations are plotted against relative time. After the control period, voluntary hyperventilation or an infusion of hypertonic $\mathrm{NaHCO}_{3}$ was begun. Recovery determinations were begun 60 minutes after termination of the alkalotic stimulus. 


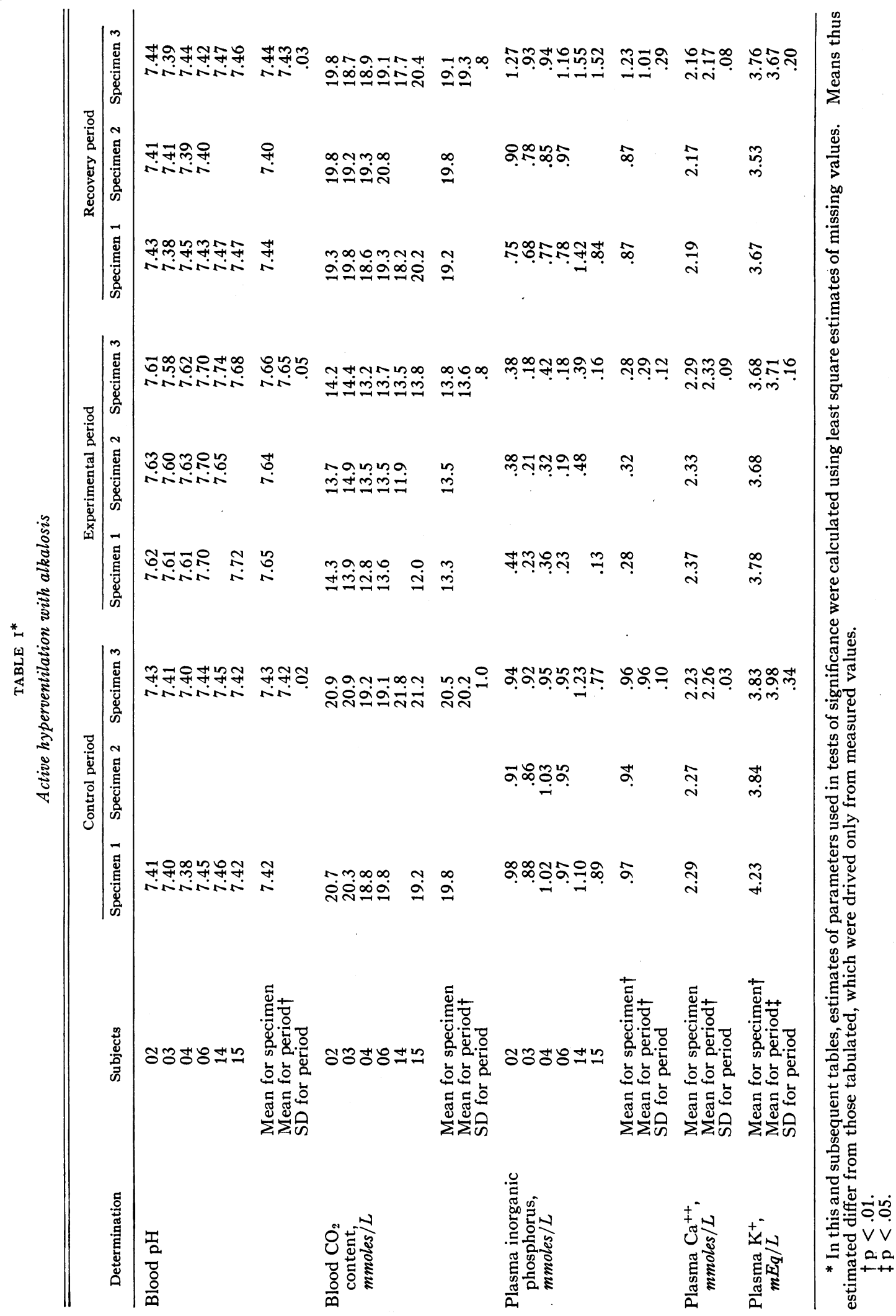


TABLE II

Urinary excretions in acute respiratory alkalosis

\begin{tabular}{|c|c|c|c|c|c|c|c|}
\hline \multirow[b]{2}{*}{ Determination } & \multirow[b]{2}{*}{ Subjects } & \multicolumn{2}{|c|}{ Control period } & \multicolumn{2}{|c|}{ Experimental period } & \multicolumn{2}{|c|}{ Recovery period } \\
\hline & & $\overline{\text { Specimen } 1}$ & Specimen 2 & Specimen 1 & Specimen 2 & Specimen 1 & Specimen 2 \\
\hline \multirow[t]{2}{*}{$\begin{array}{l}\text { Endogenous } \\
\text { creatinine } \\
\text { chromogen } \\
\text { clearance, } \\
\mathrm{ml} / \mathrm{min}\end{array}$} & $\begin{array}{l}02 \\
03 \\
04 \\
06 \\
14 \\
15\end{array}$ & $\begin{array}{l}159 \\
192 \\
115 \\
149 \\
140\end{array}$ & $\begin{array}{l}140 \\
202 \\
135 \\
142 \\
130 \\
154\end{array}$ & $\begin{array}{r}141 \\
130 \\
89 \\
\\
109\end{array}$ & $\begin{array}{r}81 \\
132 \\
123 \\
140 \\
88\end{array}$ & $\begin{array}{l}153 \\
152 \\
132 \\
152 \\
143 \\
186\end{array}$ & $\begin{array}{l}135 \\
176 \\
140 \\
135\end{array}$ \\
\hline & $\begin{array}{l}\text { Mean for specimen } \\
\text { Mean for period* } \\
\text { SD for period }\end{array}$ & 151 & $\begin{array}{r}150 \\
151 \\
26\end{array}$ & 117 & $\begin{array}{r}113 \\
115 \\
24\end{array}$ & 153 & $\begin{array}{r}146 \\
150 \\
18\end{array}$ \\
\hline \multirow[t]{2}{*}{ 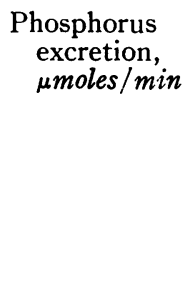 } & $\begin{array}{l}02 \\
03 \\
04 \\
06 \\
14 \\
15\end{array}$ & $\begin{array}{r}10.9 \\
3.5 \\
10.7 \\
10.3 \\
6.0\end{array}$ & $\begin{array}{r}9.8 \\
2.7 \\
11.9 \\
9.2 \\
3.9 \\
5.9\end{array}$ & $\begin{array}{l}.6 \\
.2 \\
.2 \\
\\
.2\end{array}$ & $\begin{array}{l}.2 \\
.2 \\
.1 \\
.1 \\
.2\end{array}$ & $\begin{array}{r}8.6 \\
1.4 \\
2.2 \\
1.9 \\
11.9 \\
10.4\end{array}$ & $\begin{array}{r}13.3 \\
4.8 \\
6.3 \\
5.3\end{array}$ \\
\hline & $\begin{array}{l}\text { Mean for specimen* } \\
\text { Mean for period* } \\
\text { SD for period }\end{array}$ & 8.3 & $\begin{array}{l}7.2 \\
7.7 \\
3.4\end{array}$ & .3 & $\begin{array}{l}.2 \\
.2 \\
.1\end{array}$ & 6.1 & $\begin{array}{l}7.4 \\
6.6 \\
4.3\end{array}$ \\
\hline
\end{tabular}

${ }^{*} \mathrm{p}<.01$

the mean whole blood phosphorus concentration from 1.23 to 0.59 mmole per $\mathrm{L}$.

Plasma calcium, potassium, and blood glucose did not vary in any consistent manner under the stimulus of respiratory alkalosis.

Table II and Figure 2 show renal excretion data during respiratory alkalosis. The renal excretion of $\mathrm{P}$ fell from a mean of 7.7 to $0.2 \mu$ mole per minute, and the corresponding phosphorus clearance fell from a mean of 8.0 to $1.3 \mathrm{ml}$ per minute. During the same period, there was an irregular tendency of the creatinine clearance to fall.

Potassium excretion showed an increase from a mean of $61 \mu \mathrm{Eq}$ per minute to $158 \mu \mathrm{Eq}$ per minute during alkalosis and returned to levels below control (20 $\mu \mathrm{Eq}$ per minute) during recovery.

Effects of hyperventilation without alkalosis. The effects of increased respiratory minute volume induced by voluntary active hyperventilation and by passive positive-negative pressure artificial respiration with maintenance of normal blood $\mathrm{PCO}_{2}$ and $\mathrm{pH}$ are illustrated in Figures 3 and 4.

Adequacy of control of $\mathrm{pH}$ and $\mathrm{PCO}_{2}$ is evident in both studies. No quantitative index of respiratory or alveolar minute volume is offered, but subjects performing active hyperventilation had executed the experiment previously and endeavored to match their earlier performance.
The magnitude of passive hyperventilation is reflected in the acute alkalosis induced in the third period after withdrawal of $\mathrm{CO}_{2}$ from the inspired gas mixture.

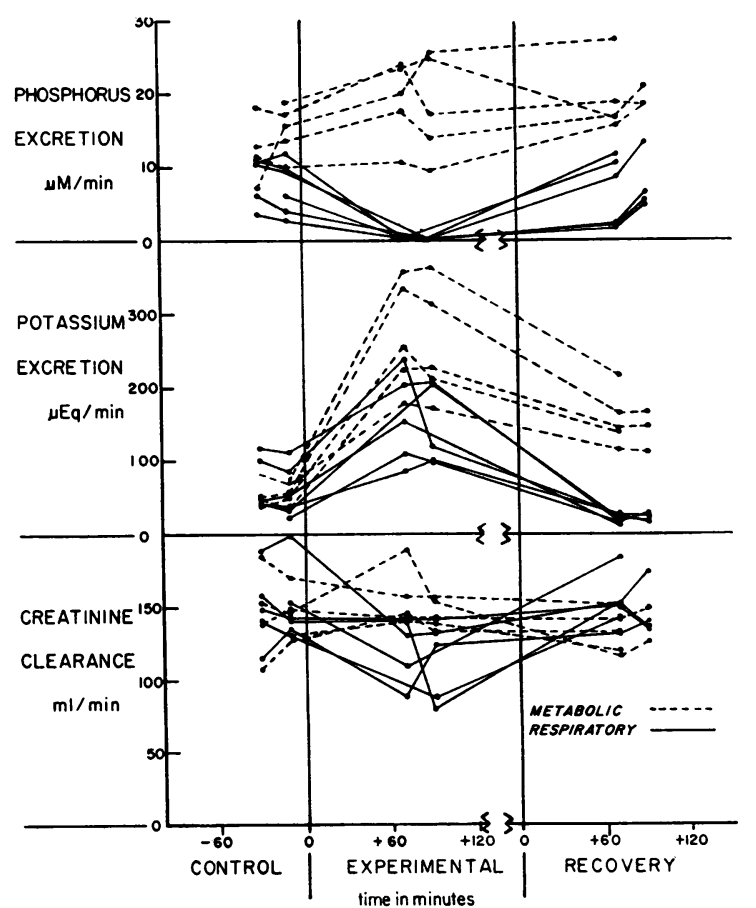

Fig. 2. URINARy EXCRETIONS IN EXPERIMENTAL ALKaLosis. The lines connect the mid-points of each collection period. 


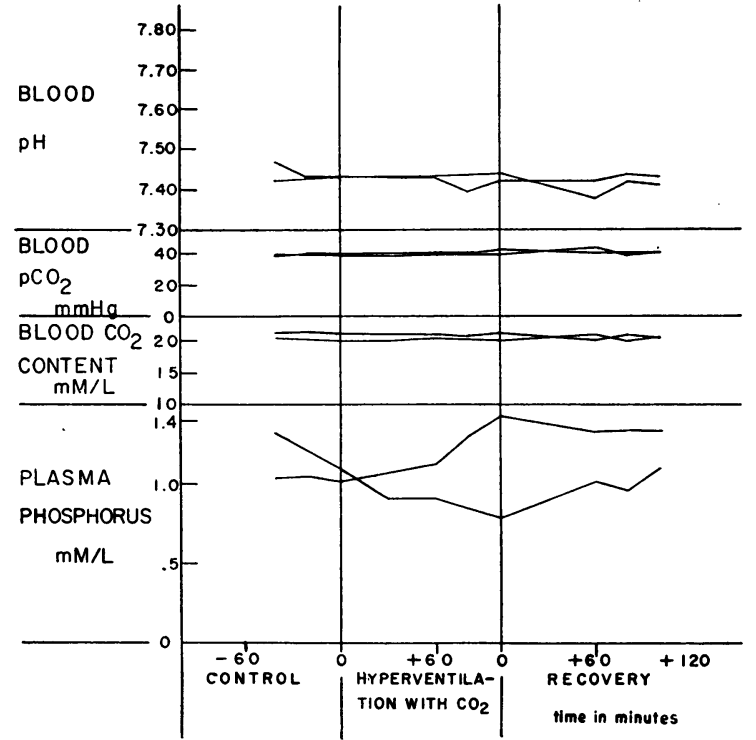

Fig. 3. ACtive hyperventilation Without alkalosis. In the experimental period the subjects were placed in a tent receiving $\mathrm{CO}_{2}$ in an amount to maintain end-expiratory $\mathrm{PCO}_{2}$ at control levels despite vigorous active hyperventilation.

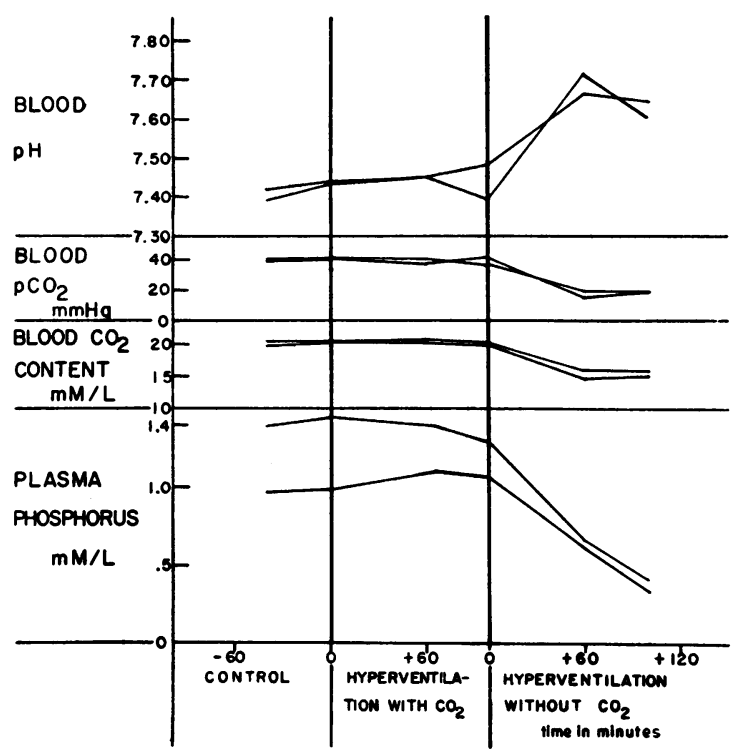

Fig. 4. Passive hyperventilation with and without $\mathrm{CO}_{2}$. After the control period, a face mask attached to a Bird Mark VIII respirator was fitted to the subject. $\mathrm{CO}_{2}$ was introduced into the circuit, and the respirator was adjusted for regulation of both inspiration and expiration so that end-expiratory $\mathrm{PCO}_{2}$ was at control levels. After 80 minutes the $\mathrm{CO}_{2}$ was removed, and the subjects went into alkalosis without change of respiration.
In three of the four subjects studied, the plasma phosphorus concentration remained constant or rose slightly. In the fourth subject a falling plasma phosphorus concentration noted during the control period continued for one period of hyperventilation without change of rate of fall and then leveled off. The third period of passive hyperventilation without added $\mathrm{CO}_{2}$ produced the typical rise of $\mathrm{pH}$ and fall of plasma phosphorus concentration. These data are not included in the series of Table I and Figure 1.

The effect of prolongation of hyperventilation with alkalosis on the variables shown in Figure 1 and 2 is graphically represented in Figure 5. After 60 minutes of hyperventilation, a steady state of alkalosis and hypophosphatemia was reached. Arterial blood glucose showed an unexplained rise at $4 \frac{1}{2}$ hours. A gradual steady fall in serum $K$ was observed.

Phosphorus excretion remained drastically de-

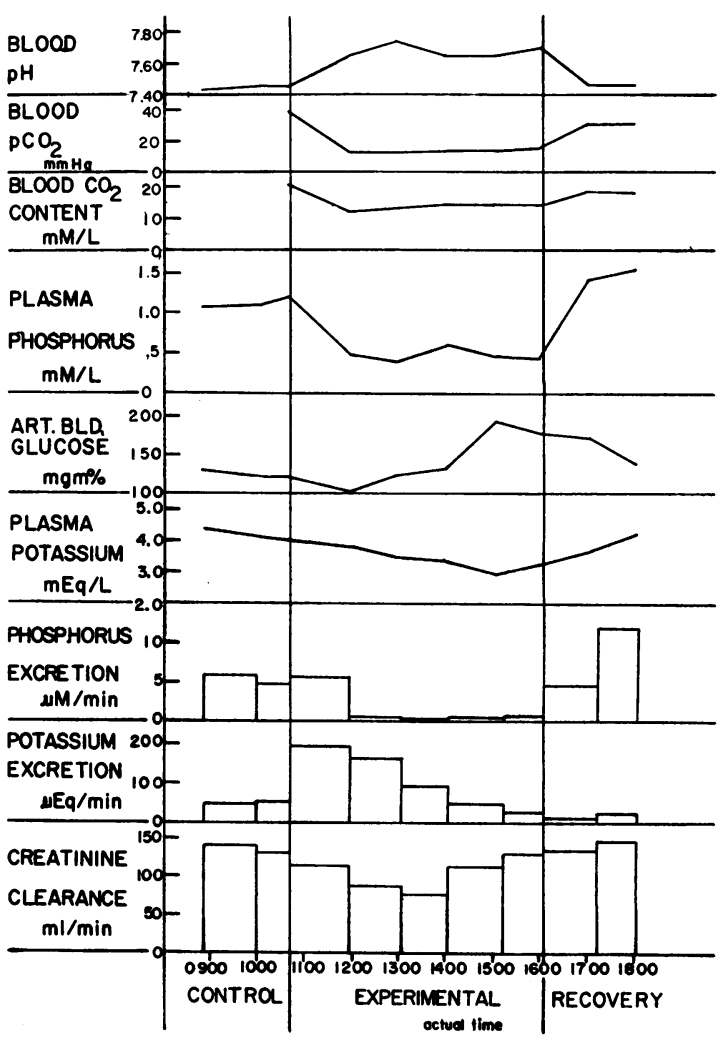

Fig. 5. Prolonged active hyperventilation with ALKALOSIS. The subject carried out active hyperventilation for 320 minutes. The level of hyperventilation was maintained by monitoring the end-expiratory $\mathrm{PCO}_{2}$ with an infrared $\mathrm{CO}_{2}$ analyzer. 
EFFECT OF ALKALOSIS ON INORGANIC PHOSPHATES IN MAN

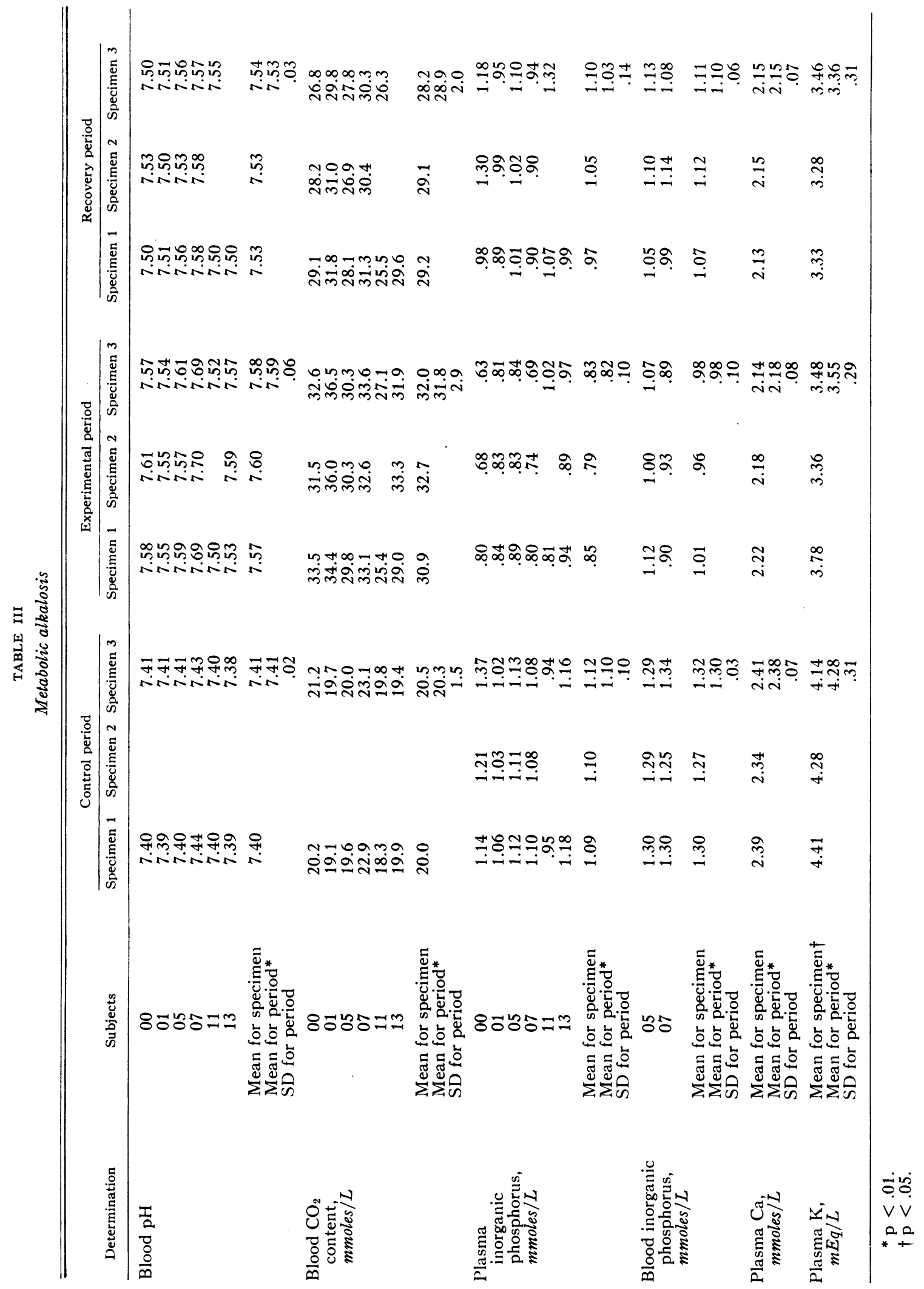


METABOLIC ALKALOSIS

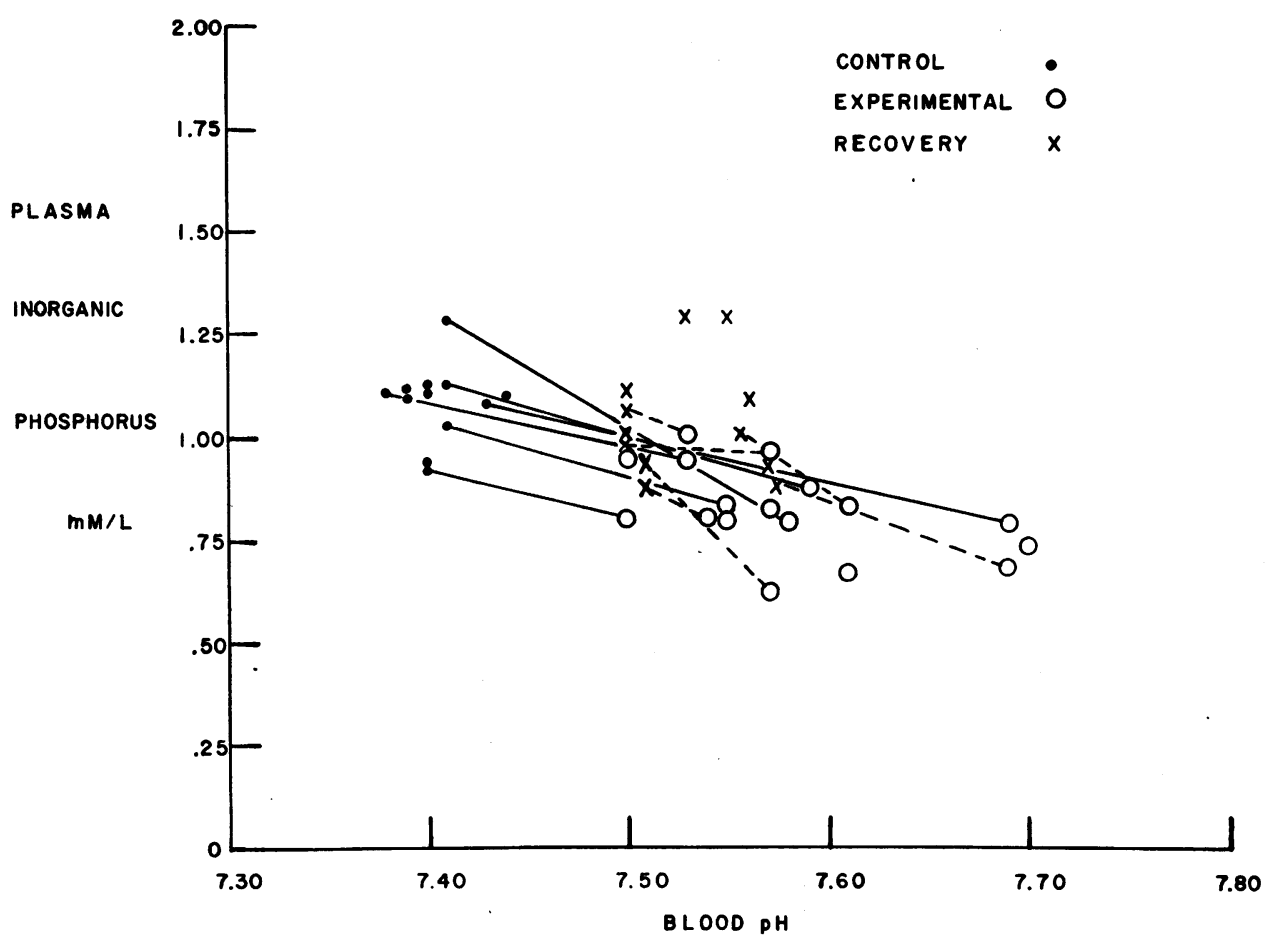

RESPIRATORY ALKALOSIS

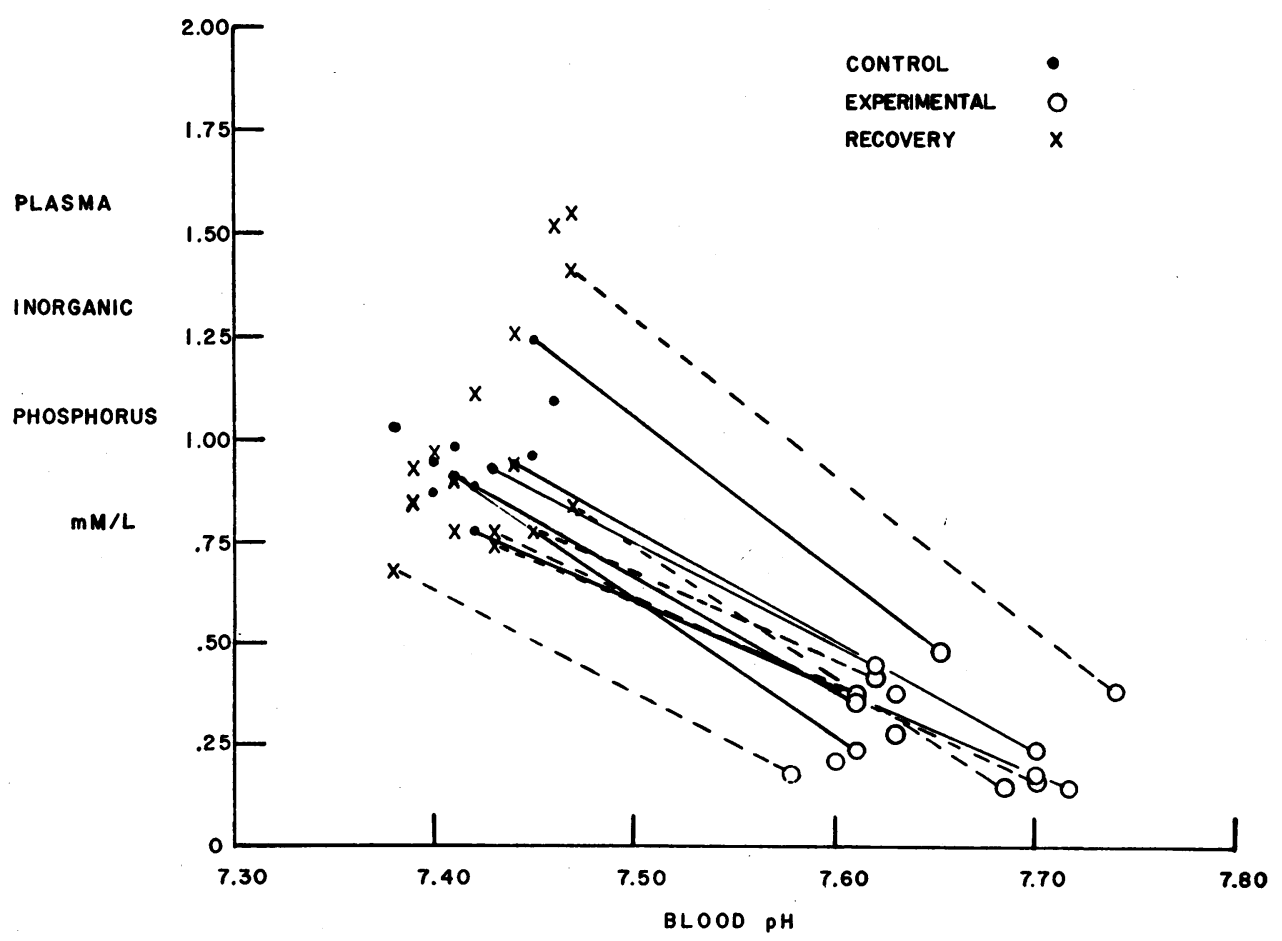

FIG. 6. 
TABLE IV

Urinary excretions in acute metabolic alkalosis

\begin{tabular}{|c|c|c|c|c|c|c|c|}
\hline \multirow[b]{2}{*}{ Determination } & \multirow[b]{2}{*}{ Subjects } & \multicolumn{2}{|c|}{ Control period } & \multicolumn{2}{|c|}{ Experimental period } & \multicolumn{2}{|c|}{ Recovery period } \\
\hline & & Specimen 1 & Specimen 2 & Specimen 1 & Specimen 2 & Specimen 1 & Specimen 2 \\
\hline \multirow[t]{2}{*}{$\begin{array}{l}\text { Endogenous } \\
\text { creatinine } \\
\text { chromagen } \\
\text { clearance, } \\
\mathrm{ml} / \mathrm{min}\end{array}$} & $\begin{array}{l}01 \\
05 \\
07 \\
11 \\
13\end{array}$ & $\begin{array}{l}153 \\
186 \\
138 \\
107\end{array}$ & $\begin{array}{l}146 \\
172 \\
149 \\
126 \\
130\end{array}$ & $\begin{array}{l}190 \\
157 \\
141 \\
146 \\
141\end{array}$ & $\begin{array}{l}154 \\
156 \\
140 \\
133 \\
138\end{array}$ & $\begin{array}{l}116 \\
151 \\
142 \\
132 \\
120\end{array}$ & $\begin{array}{l}126 \\
136 \\
149\end{array}$ \\
\hline & $\begin{array}{l}\text { Mean for specimen } \\
\text { Mean for period } \\
\text { SD for period }\end{array}$ & 146 & $\begin{array}{r}145 \\
145 \\
24\end{array}$ & 155 & $\begin{array}{r}144 \\
150 \\
16\end{array}$ & 132 & $\begin{array}{r}137 \\
134 \\
13\end{array}$ \\
\hline \multirow[t]{2}{*}{$\begin{array}{l}\text { Phosphorus } \\
\text { excretion, } \\
\mu \text { moles/min }\end{array}$} & $\begin{array}{l}01 \\
05 \\
07 \\
11 \\
13\end{array}$ & $\begin{array}{r}18.2 \\
11.4 \\
12.7 \\
7.0\end{array}$ & $\begin{array}{l}17.2 \\
10.0 \\
13.3 \\
15.6 \\
18.8\end{array}$ & $\begin{array}{l}24.1 \\
10.5 \\
17.5 \\
20.0 \\
23.3\end{array}$ & $\begin{array}{r}17.4 \\
9.4 \\
14.0 \\
25.6 \\
24.8\end{array}$ & $\begin{array}{l}18.9 \\
15.8 \\
17.0 \\
27.4 \\
16.4\end{array}$ & $\begin{array}{l}18.5 \\
18.6 \\
21.0\end{array}$ \\
\hline & $\begin{array}{l}\text { Mean for specimen } \\
\text { Mean for period } \\
\text { SD for period }\end{array}$ & 12.3 & $\begin{array}{r}15.0 \\
13.8 \\
4.0\end{array}$ & 19.1 & $\begin{array}{r}18.2 \\
18.6 \\
5.9\end{array}$ & 19.1 & $\begin{array}{r}19.4 \\
19.2 \\
3.7\end{array}$ \\
\hline
\end{tabular}

pressed throughout the experiment despite a late recovery of the depressed creatinine clearance. Potassium excretion peaked with the onset of alkalosis but gradually fell as blood levels fell.

Metabolic alkalosis. Table III gives the analyzed and derived data from the blood in six experiments during metabolic alkalosis produced by $\mathrm{NaHCO}_{3}$ infusion. The broken lines of Figure 1 represent the changes that were observed in plasma and blood. A slightly less marked degree of alkalosis was induced with a rise of mean $\mathrm{pH}$ from 7.41 to 7.59. The whole blood $\mathrm{CO}_{2}$ content rose from a mean of 20.3 to 31.8 mmoles per L. The calculated $\mathrm{PCO}_{2}$ rose from a mean of 39 to $44 \mathrm{~mm} \mathrm{Hg}$. In contrast to the respiratory alkalosis experiments, during the recovery period there was only moderate reversion of the alkalosis toward the control level, with a fall in $\mathrm{pH}$ from the mean of 7.59 during infusion to 7.53 in "recovery." Whole blood $\mathrm{CO}_{2}$ content and calculated $\mathrm{PCO}_{2}$ changed insignificantly during this period.

The plasma inorganic phosphorus concentration shows a consistent fall from a mean of 1.10 to 0.82 mmole per L. This change was uniform in direction but of smaller magnitude than that seen in respiratory alkalosis. During recovery the plasma phosphorus returned to 1.03 with only mild correction of the alkalosis. Plasma calcium and potassium fell significantly during alkalosis and remained low during recovery.

Table IV and Figure 2 record the renal excretion data with metabolic alkalosis. In spite of the falling plasma phosphorus concentration, there is a rise that is not significant in urinary phosphorus excretion from a mean of 13.8 to $18.6 \mu$ moles per minute during the infusion and to $19.2 \mu$ moles per minute during recovery. The phosphorus clearance followed the same pattern, rising from a mean of 13.1 to 22.1 and $19.7 \mathrm{ml}$ per minute. The creatinine clearance did not change significantly during the period of alkalosis or after, but a mean increase from 145 to 150 $\mathrm{ml}$ per minute was noted. Urinary potassium excretion rose from a mean of $55 \mu \mathrm{Eq}$ per minute to $265 \mu \mathrm{Eq}$ per minute during infusion and remained elevated at $151 \mu \mathrm{Eq}$ per minute during recovery.

\section{Discussion}

The "normal" serum phosphorus concentration is known to be affected by several determinants.

Fig. 6. Relation between $\mathbf{p H}$ and plasma inorganic phosphorus during acute RESPIRATORY AND METABOLIC ALKalosis. Each plasma phosphorus level is plotted against a simultaneous blood $\mathrm{pH}$. The solid line connects the last control value and the first experimental value at 60 minutes. The dotted line connects the last experimental value and the first recovery value 60 minutes later. Other points represent values during the established state. 
TABLE V

Range of values of normal serum $P$

\begin{tabular}{clll}
\hline \hline \multirow{2}{*}{ Mean \pm SD } & \multicolumn{1}{c}{ Range } & Range & Author \\
\hline \multirow{2}{*}{$m g / 100 m l$} & \multicolumn{1}{c}{$m g / 100 m l$} & mmoles $/ L$ & \\
& $2.4-5.0$ & $.78-1.62$ & $(11)$ \\
$2.4 \pm .7$ & $2.0-4.8^{*}$ & $.65-1.55^{*}$ & $(12)$ \\
& $3-4$ (adults) & $1.0-1.3$ & $(14)$ \\
& $5-6$ (child) & $1.6-1.9$ & $(14)$ \\
$3.9 \pm .5$ & $2.4-4.2$ & $.78-1.36$ & $(15)$ \\
& $2.9-4.9$ (adults)* & $.94-1.87^{*}$ & $(17)$ \\
$3.2 \pm .5$ & $4.3-6.0$ & $1.39-1.94$ & $(18)$ \\
& $2.6-4.3 *$ & $.84-1.39^{*}$ & $(21)$ \\
3.4 & $2.7-3.7$ & $.87-1.20$ & $(34)$ \\
& $2.5-4.5$ & $.81-1.45$ & $(37)$ \\
& $2.8-3.9$ & $.90-1.26$ & $(38)$ \\
\hline
\end{tabular}

$*$ Mean $\pm 2 \mathrm{SD}$.

Dietary phosphorus intake (20), stage of growth $(14,34)$, and time of day $(35,36)$ contribute to the variability of the fasting serum phosphorus concentration. Table $\mathrm{V}$ gives the range of normal values reported by several authors.

The present data show that in normal man, physiological and experimental disturbances of acid-base balance can modify the serum phosphorus concentration in a predictable manner. The inclusion of patients with unsuspected disturbances of acid-base balance in normal series increases the apparent range of normal variation and impairs the sensitivity of the serum phosphorus concentration in the diagnosis of disease.

The relationship between plasma phosphorus concentration and $\mathrm{pH}$ is shown in Figure 6 . Control values are closely grouped in both experiments, but a large scatter is seen in the recovery periods of both groups. Inspection of Tables I and III reveals a progressive rise in plasma phosphorus concentration without a corresponding change in $\mathrm{pH}$ at the end of recovery, suggesting a rebound phenomenon. Figure 7 represents mean values for all subjects for each specimen and shows the sequence of changes observed.

Two important differences between respiratory and metabolic alkalosis might account for the difference in fall of phosphorus concentration. The elevated total $\mathrm{CO}_{2}$ in metabolic alkalosis is in marked contrast to its depression in respiratory alkalosis. If phosphorus disappears by an ion exchange process, an elevated bicarbonate might compete with phosphorus for sites of exchange and minimize the fall in phosphorus concentra- tion in metabolic alkalosis. This competition for binding sites has been described in vitro in bone salts (39).

The other difference between the two alkaloses is in the rate of change of hydrogen ion concentration in the intracellular compartment. As has been pointed out by Robin (40) acute changes in respiratory acid-base relationships are transmitted into the cell much more rapidly than metabolic acid-base changes. If the fall in plasma phosphorus concentration described here is attributable to intracellular migration of the element, a more rapid disappearance from the plasma might be expected from the greater intracellular alkalosis of hyperventilation.

The site of disappearance of phosphorus from the extracellular fluid is a matter of major inter-
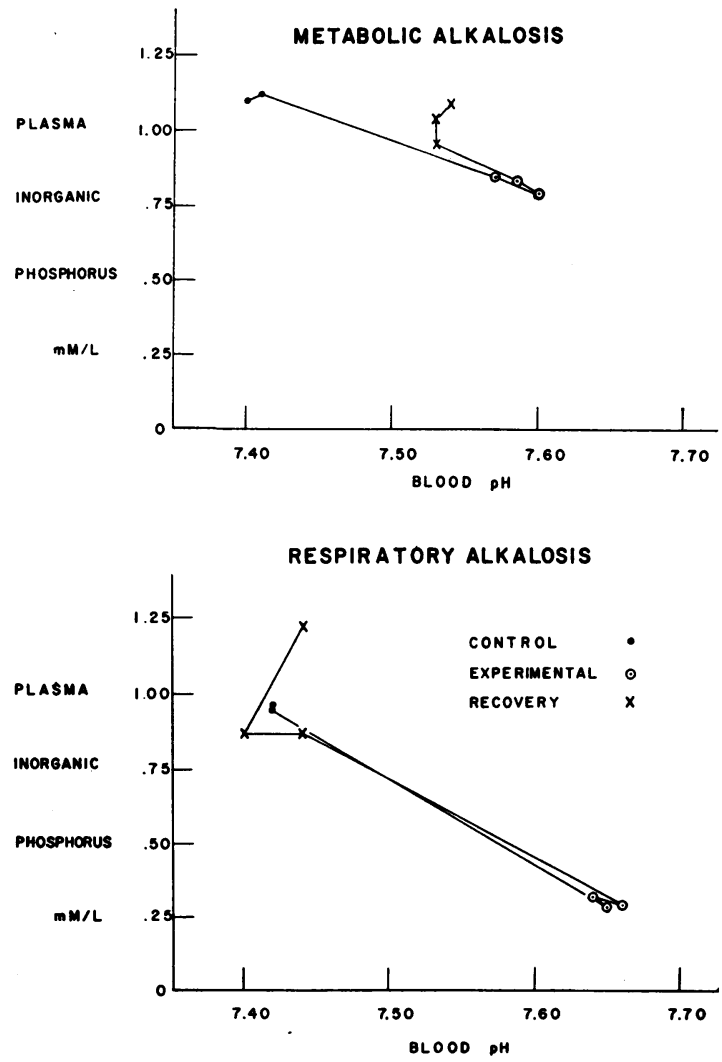

Fig. 7. Relation between mean pH and plasma INORGANIC PHOSPHORUS DURING ACUTE ALKALOSIS. The $\mathrm{pH}$ and plasma phosphorus values for all blood specimens drawn at identical experimental times were averaged and the means plotted against each other. The solid line represents the temporal sequence of the specimens. 
est. The amount that must be accounted for can be estimated at a maximum of 0.75 mmole per $\mathrm{L}$ in $17 \mathrm{~L}$ of extracellular fluid or 12.7 mmoles.

Rapoport and associates (4) suggested that the fall in phosphorus concentration with short term hyperventilation might be due to changes in carbohydrate metabolism. Haldane and Wigglesworth (41) showed in 1920 that with hyperventilation the glucose tolerance curve becomes diabetic in type. This impairment of glucose utilization should cause a rise in serum phosphorus rather than a fall. In the studies reported here, there is no evidence of the fall in blood glucose that is seen when rapid deposition of glycogen lowers the serum phosphorus after insulin administration or secretion $(42,43)$.

The fall in plasma inorganic phosphorus is not accounted for by movement into the erythrocytes unless there is a rapid conversion to organic phosphates. The inorganic phosphorus of whole blood changes in the same direction as plasma phosphorus. This indicates that phosphorus has migrated out of the vascular compartment or has become organically bound. A slow conversion to organic phosphates under conditions of in vitro glycolysis at low $\mathrm{CO}_{2}$ tensions has been described (44), but in the absence of accelerated glycolysis this phenomenon is unlikely to proceed at the rate seen in the acute experiments.

The renal excretion data clearly show that external losses of phosphorus do not account for the fall in plasma phosphorus concentration. In respiratory alkalosis the excretion falls nearly to zero. In metabolic alkalosis the phosphorus excretion rises by an average of $5 \mu$ moles per minute, but this rate for 90 minutes would produce an increase over control of only 0.45 mmole of phosphorus. This is insufficient to account for the phosphorus lost from the extracellular fluid. The distinctly greater creatinine clearances associated with bicarbonate infusion may well account for the greater phosphorus excretion in metabolic alkalosis.

The possibility that alkalosis produces the precipitation of some salt of phosphate needs to be considered (45). The molar changes in calcium concentration in plasma are consistently much smaller than the changes in phosphorus concentration with alkalosis. Since in bone salts the molar ratio $\mathrm{Ca}: \mathrm{P}$ is in the range 1.3 to 2.0 (45), it is unlikely that precipitation of calcium phosphate accounts for the fall in serum phosphorus. Corresponding changes in magnesium concentration have not been studied in these experiments.

With respiratory alkalosis, a rise in serum citrate from 1.80 to $2.77 \mathrm{mg}$ per $100 \mathrm{ml}$ (.094 to .145 mmole per L) and a rise in serum lactate from 8.3 to $16.3 \mathrm{mg}$ per $100 \mathrm{ml}$ (.92 to 1.82 mmoles per L) have been reported by Axelrod (7). The fall in serum phosphorus reported at the same time was from 3.51 to $2.61 \mathrm{mg}$ per 100 $\mathrm{ml}$ ( 1.13 to 0.84 mmole per $\mathrm{L}$ ). If citrate is assumed to have a valence of -3 and lactate a valence of -1 , and if $80 \%$ of the phosphorus has a valence of -2 and the rest of -1 , a crude calculation of equivalence may be made. In the plasma $1.05 \mathrm{mEq}$ per $\mathrm{L}$ of organic acids have appeared, and $0.54 \mathrm{mEq}$ per $\mathrm{L}$ of phosphorus have been lost. This calculation makes no correction for activity of the components exchanged, but the order of magnitude is such that an ion exchange mechanism seems possible. Similar data for metabolic alkalosis are not available. Preliminary studies of a-v differences across cortical bone and parenchymal organs in the dog suggest that exchange for lactate in the soft tissues rather than exchange in bone is the site of disappearance of phosphorus in alkalosis.

\section{Summary}

Acute respiratory and metabolic alkalosis have been shown to depress plasma phosphorus concentration in normal man. The fall in plasma phosphorus concentration is greater in respiratory than in comparable levels of extracellular metabolic alkalosis. This fall is not attributable to increased renal excretion or to migration into red blood cells. The evaluation of low serum phosphorus concentrations should always be carried out with a knowledge of the $\mathrm{pH}$ and total $\mathrm{CO}_{2}$ content of the plasma.

\section{Appendix}

The standard deviation of the mean of a pair of duplicates was considered to be the index of precision and is designated SD. When duplicate determinations differed by more than 2 to $4 \mathrm{SD}$, depending upon their absolute values, a new sample was analyzed, and the pair of 
values closest together was utilized. Statistical indexes for the various types of analyses are shown in the following table.

\begin{tabular}{|c|c|c|c|}
\hline Determination & Units & Range & $\mathrm{SD}$ \\
\hline Blood $\mathrm{pH}$ & & $7.38-7.72$ & .005 \\
\hline $\begin{array}{l}\text { Blood } \mathrm{CO}_{2} \text { con- } \\
\text { tent }\end{array}$ & mmoles/L & $13.6-22.2$ & .24 \\
\hline $\begin{array}{l}\text { Plasma inorganic } \\
\text { phosphorus }\end{array}$ & mmoles/L & $.18-1.65$ & .016 \\
\hline $\begin{array}{l}\text { Blood inorganic } \\
\text { phosphorus }\end{array}$ & mmoles/L & $.39-1.67$ & .050 \\
\hline $\begin{array}{l}\text { Urine inorganic } \\
\text { phosphorus }\end{array}$ & mmoles/L & $1.2-116.2$ & .50 \\
\hline Plasma calcium & mmoles/L & $2.03-2.70$ & .03 \\
\hline Plasma potassium & $\mathrm{mEq} / \mathrm{L}$ & $3.00-4.90$ & .11 \\
\hline Urine potassium & $\mathrm{mEq} / \mathrm{L}$ & $1.8-80.0$ & .74 \\
\hline Hematocrit & $\mathrm{vol} / 100 \mathrm{ml}$ & $39.7-56.4$ & .2 \\
\hline Blood glucose & $\mathrm{mg} / 100 \mathrm{ml}$ & $110-202$ & 1.1 \\
\hline $\begin{array}{l}\text { Plasma creatinine } \\
\text { chromogen }\end{array}$ & $\mathrm{mg} / 100 \mathrm{ml}$ & $.72-1.34$ & .02 \\
\hline $\begin{array}{l}\text { Urine creatinine } \\
\text { chromogen }\end{array}$ & $\mathrm{mg} / \mathrm{ml}$ & $.062-1.187$ & .065 \\
\hline
\end{tabular}

1. Haldane, J. B. S., V. B. Wigglesworth, and C. E. Woodrow. The effect of reaction changes on human inorganic metabolism. Proc. roy. Soc. B 1924, 96, 1.

2. Giebisch, G., L. Berger, and R. F. Pitts. The extrarenal response to acute acid-base disturbances of respiratory origin. J. clin. Invest. 1955, 34, 231.

3. Brassfield, C. R., and V. G. Behrmann. A correlation of the $\mathrm{pH}$ of arterial blood and urine as affected by changes in pulmonary ventilation. Amer. J. Physiol. 1941, 132, 272.

4. Rapoport, S., C. D. Stevens, G. L. Engel, E. B. Ferris, and M. Logan. The effect of voluntary overbreathing on the electrolyte equilibrium of arterial blood in man. J. biol. Chem. 1946, 163, 411.

5. Brown, E. B., Jr., G. S. Campbell, J. O. Elam, F. Gollan, A. Hemingway, and M. B. Visscher. Electrolyte changes with chronic passive hyperventilation in man. J. appl. Physiol. 1949, 1, 848.

6. Stanbury, S. W., and A. E. Thomson. The renal response to respiratory alkalosis. Clin. Sci. 1952, $11,357$.

7. Axelrod, D. R. Organic acids and calcium in hyperventilation. J. appl. Physiol. 1961, 16, 709.

8. Okel, B. B., and J. W. Hurst. Prolonged hyperventilation in man. Associated electrolyte changes and subjective symptoms. Arch. intern. Med. 1961, 108, 757.

9. Barker, E. S., R. B. Singer, J. R. Elkinton, and J. K. Clark. The renal response in man to acute experimental respiratory alkalosis and acidosis. $\mathrm{J}$. clin. Invest. 1957, 36, 515.
10. Bartter, F. C. The parathyroids. Ann. Rev. Physiol. 1954, 16, 429.

11. Chambers, E. L., Jr., G. S. Gordan, L. Goldman, and E. C. Reifenstein, Jr. Tests for hyperparathyroidism: tubular reabsorption of phosphate, phosphate deprivation, and calcium infusion. J. clin. Endocr. 1956, 16, 1507.

12. Bogdonoff, M. D., A. H. Woods, J. E. White, and F. L. Engel. Hyperparathyroidism. Amer. J. Med. 1956, 21, 583.

13. Nordin, B. E. C., and R. Fraser. The Indirect Assessment of Parathyroid Function. Ciba Foundation Symposium on Bone Structure and Metabolism. Boston, Little, Brown, 1956, p. 222.

14. Copp, D. H. Calcium and phosphorus metabolism. Amer. J. Med. 1957, 22, 275.

15. Talpers, S. J., and J. D. Stein, Jr. Tubular reabsorption of phosphorus as a measure of parathyroid activity. Metabolism 1959, 8, 170.

16. Kyle, L. H., M. Shaaf, and J. J. Canary. Phosphate clearance in the diagnosis of parathyroid dysfunction. Amer. J. Med. 1958, 24, 240.

17. Reynolds, T. B., H. Lanman, and N. Tupikova. Reevaluation of phosphate excretion tests in the diagnosis of hyperparathyroidism. Arch. intern. Med. 1960, 106, 48.

18. Fraser, D. Clinical manifestations of genetic aberrations of calcium and phosphorus metabolism. J. Amer. med. Ass. 1961, 176, 281.

19. Beisel, W. R., E. S. Gerard, K. G. Barry, E. G. Herndon, Jr., W. H. Meroney, and L. H. Kyle. Phosphate abnormalities in hyperparathyroidism. Metabolism 1961, 10, 771.

20. Pronove, P., and F. C. Bartter. Diagnosis of hyperparathyroidism. Metabolism 1961, 10, 349.

21. Keating, F. R., Jr. Diagnosis of primary hyperparathyroidism. J. Amer. med. Ass. 1961, 178, 547.

22. Rasmussen, H. Parathyroid hormone. Nature and mechanism of action. Amer. J. Med. 1961, 30, 112.

23. Shock, N. W., and A. B. Hastings. Studies of the acid-base balance of the blood; 1 . A microtechnique for the determination of the acid-base balance of the blood. J. biol. Chem. 1934, 104, 565.

24. Singer, R. B., J. Shohl, and D. B. Bluemle. Simultaneous determination of $\mathrm{pH}, \mathrm{CO}_{2}$ content, and cell volume on $0.1 \mathrm{ml}$ aliquots of cutaneous blood. Clin. Chem. 1955, 1, 287.

25. Peters, J. P., and D. D. Van Slyke. Quantitative Clinical Chemistry. Vol. II. Methods. Baltimore, Williams \& Wilkins, 1932, p. 283.

26. Singer, R. B., and A. B. Hastings. An improved clinical method for the estimation of disturbances of the acid-base balance of human blood. Medicine (Baltimore) 1948, 27, 223.

27. Fiske, C. H., and Y. Subbarow. The colorimetric determination of phosphorus. J. biol. Chem. 1925, $66,375$. 
28. Folin, O., and H. Wu. A system of blood analysis. J. biol. Chem. 1919, 38, 81 .

29. Bonsnes, R. W., and H. H. Taussky. On the colorimetric determination of creatinine by the Jaffe reaction. J. biol. Chem. 1945, 158, 581.

30. Fales, F. W. A micromethod for the determination of serum calcium. J. biol. Chem. 1953, 204, 577.

31. Nelson, N. A photometric adaptation of the Somogyi method for the determination of glucose. J. biol. Chem. 1944, 153, 375.

32. Snedecor, G. W. Statistical Methods Applied to Experiments in Agriculture and Biology. Ames, Iowa, The Iowa State College Press, 5th ed., 1956, p. 291.

33. Ibid., p. 246.

34. Albright, F., and E. C. Reifenstein, Jr. The Parathyroid Glands and Metabolic Bone Disease. Baltimore, Williams and Wilkins, 1948, p. 4.

35. Ollayos, R. W., and A. W. Winkler. Urinary excretion and serum concentration of inorganic phosphate in man. J. clin. Invest. 1943, 22, 147.

36. Stanbury, S. W., and A. E. Thomson. Diurnal variations in electrolyte excretion. Clin. Sci. 1951, 10, 267.

37. Sackner, M. A., A. P. Spivack, and L. J. Balian. Hypocalcemia in the presence of osteoblastic metastases. New Engl. J. Med. 1960, 262, 173.
38. Henneman, P. H., P. H. Benedict, A. P. Forbes, and H. R. Dudley. Idiopathic hypercalcuria. New Engl. J. Med. 1958, 259, 802.

39. Neuman, W. F., T. Y. Toribara, and B. J. Mulryan. The surface chemistry of bone. IX. Carbonate: phosphate exchange. J. Amer. chem. Soc. 1956, 78, 4263.

40. Robin, E. D. Of men and mitochondria-intracellular and subcellular acid-base relations. New Engl. J. Med. 1961, 265, 780.

41. Haldane, J. B. S., V. B. Wigglesworth, and C. E. Woodrow. The effect of reaction changes on human carbohydrate and oxygen metabolism. Proc. roy. Soc. B 1924, 96, 15.

42. Wigglesworth, V. B., C. E. Woodrow, W. Smith, and L. B. Winter. On the effect of insulin on blood phosphate. J. Physiol. (Lond.) 1923, 57, 447.

43. Harrop, G. A., Jr., and E. M. Benedict. The participation of inorganic substances in carbohydrate metabolism. J. biol. Chem. 1924, 59, 683.

44. Tulin, M., T. S. Danowski, P. M. Hald, and J. P. Peters. The distribution and movements of inorganic phosphate between cells and serum of human blood. Amer. J. Physiol. 1947, 149, 678.

45. Neuman, W. F., and M. W. Neuman. The Chemical Dynamics of Bone Mineral. Chicago, University of Chicago Press, 1958, p. 41. 